\title{
sciendo
}

\author{
ANITA MAJCHROWSKA
}

\section{Pharmaceutical care - a chance or necessity in the context of Polish self-medication}

\begin{abstract}
Introduction. The modern pharmaceutical care is supposed to meet numerous demands resulting from the presence and broad availability of OTC medicines. In this case the pharmacist becomes the primary advisor as for the application of medicines which are not prescribed by a doctor.

Aim. The aim of the study was to recognize the position of pharmacists employed in the pharmacy towards pharmaceutical care, possibilities to conduct it and barriers of its implementation.

Material and method. The researchers conducted a survey with elements of a questionnaire interview. The number of 186 pharmacists who work in pharmacies in the province of Lublin took part in the research.

Results. The surveyed perceive the benefits of performing pharmaceutical care: increased prestige of the profession, greater satisfaction with their job $-44.9 \%$ choices for each; increase of the effectiveness of pharmacotherapy $(54.6 \%)$ and treatment (44.3\%). The major barriers to introducing pharmaceutical care include insufficient education of pharmacists (33.7\%) and lack of solid co-operation with the doctor $(32.6 \%)$.

Conclusions. Pharmacists are aware of the importance of pharmaceutical care, although they identify a number of barriers which hinder its effective introduction.
\end{abstract}

Keywords: pharmaceutical care, self-medication, OTC medicines.

DOI: $10.2478 /$ pjph-2018-0017

\section{INTRODUCTION}

The dynamic development of the pharmaceutical industry, following the modern discoveries in the field of medicine and pharmacy, creates conditions for more and more effective treatment of diseases, supporting doctors and patients in coping with health issues. Unfortunately, it is also a threat, because easy availability of drugs may contribute to their abuse $[1,2]$. Both in Poland and throughout the world, many medicines once issued on the basis of a medical prescription can now be bought over the counter $[3,4]$, and this not only in pharmacies, but also in other retail outlets, such as supermarkets or petrol stations. This contributes to purchase of medicines, which are out of control of practitioners, and thus their irrational use, which entails serious health effects [5]. The broad offer of the pharmaceutical market, easy availability of medicines and advertising-driven belief that pharmacotherapy is always effective - cause, in modern societies, a huge increase in drug consumption, both those available on prescription and without it (medicines from the OTC group) [6].

Additionally, this phenomenon is stimulated by the growing popularity of self-medication as one of the methods of satisfying health needs $[7,8]$. Poles are increasingly curing themselves, and they only go to the doctor when the therapy they are using alone does not bring the expected results. According to the latest research by the Centre for Public Opinion Research [9] almost nine out of ten adult Poles (89\%) used over-the-counter drugs during the year preceding the study. The most common were painkillers and anti-inflammatory drugs (68\%), as well as those mitigating the symptoms of colds or flu (68\%). Over half of the respondents $(52 \%)$ used vitamins, minerals and agents that improve the body's general immunity during this time. Over a quarter of adults (27\%) used OTC drugs to alleviate digestive disorders [9].

According to the same research, in case of situation of experiencing the symptoms of a disease, the independent use of over-the-counter drugs is declared by $21 \%$ of respondents, immediately following the popularity of a medical consultation and the use of medicines prescribed by a doctor $(30 \%)$ and the use of the so-called home remedies to the problem (29\%) [9]. Such a way of reacting to a disease brings many advantages (reduced costs of treatment, increased responsibility for one's health, time saving), but also threats such as delaying doctor's appointments, drug interactions, polypharmacies $[2,10,11]$. Self-medication is fostered by the growing level of health awareness and health competence of Poles, as well as by the dysfunctionality of Polish medical institutions. Difficulties in accessing the doctor, inappropriate doctor-patient relations and not very high level of trust of Polish patients to doctors [12] deepen the tendency to exclude the doctor from the therapeutic process and seek help directly in the pharmacy. The pharmacist is available to the patient for many hours 
a day, without prior appointment. He or she is also more and more often the first (or even the only) person who is presented by the patient with his/her health problems $[13,14]$. He or she is also the last member of the medical team with whom the patient contacts before deciding to start using the prescribed medicine [14]. This situation puts special challenges ahead of the modern pharmacy. Pharmacists employed in a pharmacy are increasingly expected to be consulted on healthy lifestyle and help in self-medication and solving health problems of patients [15-17].

An appropriate tool for the implementation of these tasks may be modern pharmaceutical care run in Polish pharmacies [18]. The Act on Pharmaceutical Chambers defines pharmaceutical care as: 'a documented process in which the pharmacist, in cooperation with the patient and doctor, and if necessary with representatives of other medical professions, supervises the proper course of pharmacotherapy in order to obtain specific effects improving the quality of life of the patient' [19]. Although care understood in this way gives an opportunity to implement broad prevention and health promotion $[20,21]$, it is kept in its statutory borders only in a few pharmacies across Poland.

\section{AIM}

The objective of the research was to discover the position of pharmacists working in pharmacies, towards pharmaceutical care. Particular attention was paid to the barriers to its implementation identified by pharmacists and the perceived opportunities/chances for its implementation.

\section{MATERIAL AND METHODS}

The research was conducted using survey method, with use of the structured interview technique, among 186 pharmacists working in pharmacies of the Lublin province. The tool was a questionnaire elaborated by the Author of the present paper. The surveyed pharmacists usually worked in a large city with over 100,000 inhabitants $(45.5 \%)$, in smaller towns from 20 to 100 thousand residents $(31.6 \%)$ and in the villages and small towns up to 20 thousand residents $-23 \%$. When it comes to $43.9 \%$ of respondents, they had less than 5 years of work experience in the pharmacy, $33.2 \%$ from 5 to 15 years, and $23 \%$ over 15 years.

The obtained results were subjected to statistical analysis. The values of the analyzed parameters, due to their nominal scale of measurement, were characterized by their total number and percentage. To assess the existence of differences or dependencies between the analyzed parameters, a homogeneity or $\chi$ independence test were used. A 5\% error of inference and associated significance level $\mathrm{p}<0.05$ indicating the existence of statistically significant differences or dependencies were adopted.

\section{RESULTS}

According to the research, the vast majority of pharmacists working in pharmacies are in favour of running pharmaceutical care. Only $18.2 \%$ of respondents opposed pharmaceutical care in Polish pharmacies, and $4.3 \%$ had no opinion. The other respondents $(77.5 \%$ in total) are of the opinion that pharmacies should implement this form of patient care. The level of acceptance for pharmaceutical care was not influenced by any independent variables (seniority in the profession, place of work, age of respondents).

The surveyed pharmacists see the benefits of running pharmaceutical care, both for their professional group (increased prestige of the pharmacist and improvement of job satisfaction $-44.9 \%$ of each of the justifications), and for the broadly understood good of patients: improvement of pharmacotherapy effectiveness $(54.6 \%)$ and increase in the effectiveness of treatment, and hence greater patient satisfaction (44.3\%). Among the independent variables, the place of work and the nature of the choice of profession by pharmacists turned out to be significant. Persons employed in pharmacies in mediumsized towns (from 20,000 to 100,000 inhabitants) and those who independently decided to choose a profession, more often quoted benefits related to the profession of pharmacist (increased prestige, increased satisfaction) $(\mathrm{p}<0.05)$.

Despite the high level of acceptance for the process of implementing pharmaceutical care, it is carried out only in few pharmacies. Of all the pharmacists examined, only a little more than every tenth respondent confirms that the pharmacy in which he or she works carries out pharmaceutical care $(12.5 \%)$. More than every third pharmacist (34.4\%) admits that although his/ her pharmacy does not currently take care of patients, they are considering introducing it. However, half of the respondents $(50.5 \%)$ confirm that the pharmacy in which they work does not provide pharmaceutical care and does not intend to introduce it.

The biggest obstacle to the introduction of pharmaceutical care is - according to the respondents - the lack of knowledge of the pharmacists themselves and their insufficient substantive preparation for exercising such a form of patient/client care in the pharmacy $(33.7 \%)$. Statistically, pharmacists with the longest experience in a pharmacy indicated this barrier more often $(p<0.05)$. An equally important barrier, in the opinion of the respondents, is the lack of reliable cooperation with physicians. Almost every third pharmacist surveyed believes so $(32.6 \%)$. A little more than every fifth $(21.4 \%)$ blames, for the difficulty of introducing this care, the lack of adequate spatial conditions in Polish pharmacies, and only $3.7 \%$ indicate a barrier in the form of a distrustful attitude of patients towards such an offer of pharmacies.

The surveyed pharmacists, assessing how currently pharmaceutical care is perceived in the environment of pharmacists, most often state that 'pharmacists are afraid to take responsibility for the health of the patient' - this opinion is expressed by almost every third respondent (31\%). Almost the same percentage states that 'pharmacists believe that they do not have adequate competences to provide care' (30\%). This gives a total of over $60 \%$ of opinions expressing environmental concerns related to pharmaceutical care. Only a little more than every fourth respondent (26.2\%) believes that 'pharmacists see an opportunity for professional development and raising the prestige of the profession in pharmaceutical care', and $12.3 \%$ are convinced that 'Polish pharmacists are prepared to run pharmaceutical care, and only need the right legal solutions'. It is worth noting that the statistically significant variables influencing these assessments were the age of respondents and their seniority in the profession. Younger respondents, and thus having a shorter practice in the profession of pharmacist - demonstrated greater tendencies to more favourable assessments of both the opportunities and chances for care provided by the pharmacists' community $(\mathrm{p}<0.05)$. 


\section{DISCUSSION}

Modern pharmaceutical care must now meet many challenges related primarily to the existence and high availability of OTC drugs. Pharmacists working in pharmacies themselves admit that Poles buy (and hence use) too many analgesics, anti-inflammatory drugs, sedatives and sleeping pills [21]. Medicine remains helpless in the face of the universality of the phenomenon of self-medication conditioned by both the dysfunctional health care and the health culture of the laity. In this situation, the role of the pharmacist/apothecary, who is the most important adviser of the patient in the field of using these drugs which are not subject to regulation on medical competence, is significant [22].

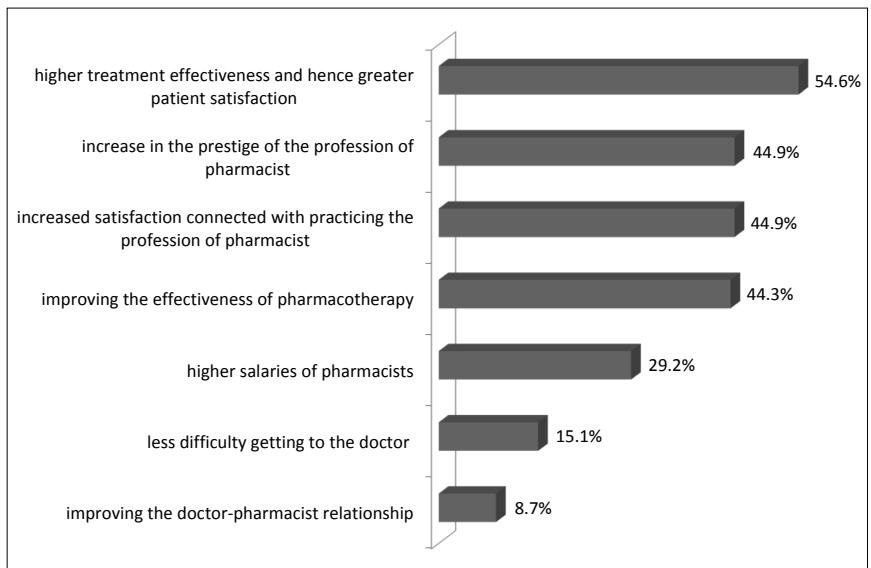

FIGURE 2. Benefits of running pharmaceutical care according to pharmacists?

Respondents could choose more than one option, hence the percentages do not add up to 100 .

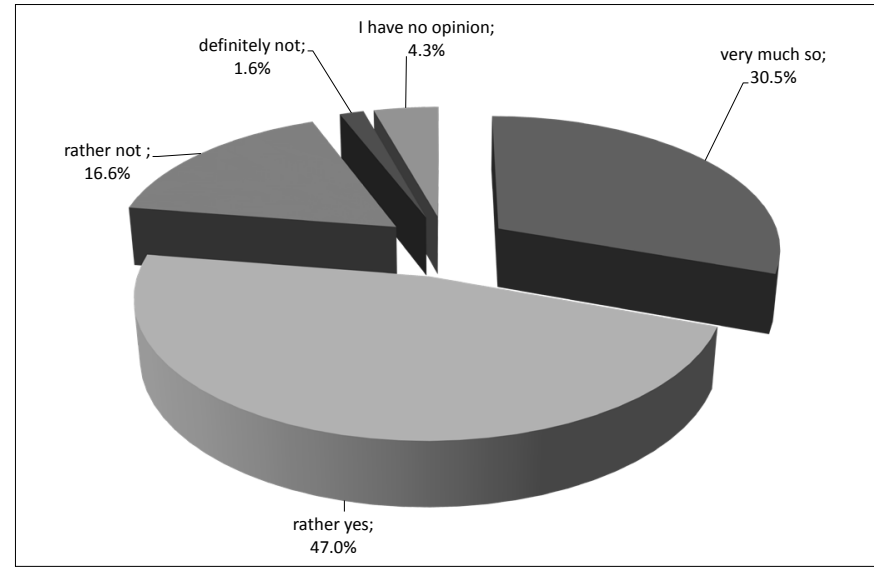

FIGURE 1. Should pharmaceutical care be run in Polish pharmacies?

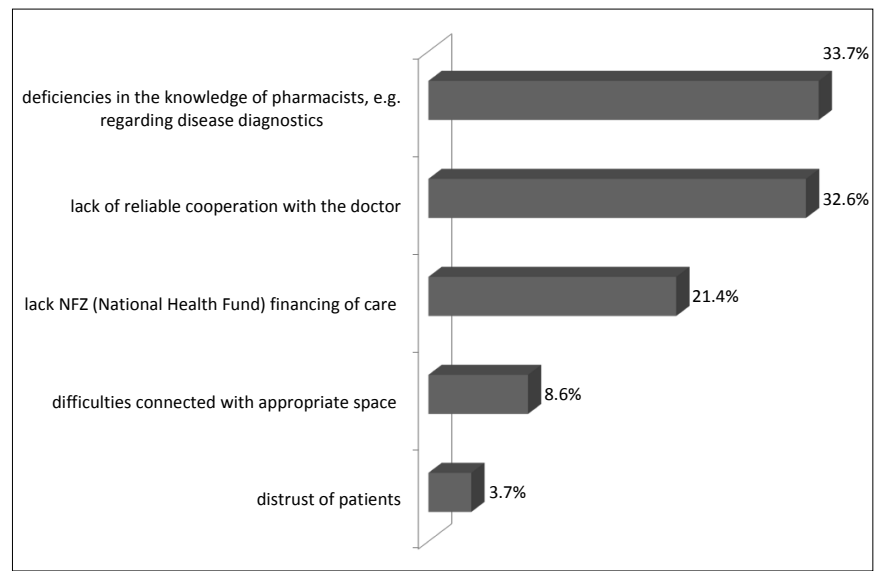

FIGURE 3. Barriers to implementing pharmaceutical care according to pharmacists.

Respondents could choose more than one option, hence the percentages do not add up to 100 .

TABLE 1. Benefits of running pharmaceutical care according to pharmacists.

\begin{tabular}{|c|c|c|c|c|c|c|c|c|c|}
\hline & \multicolumn{3}{|c|}{ Age } & \multicolumn{3}{|c|}{ Workplace } & \multicolumn{3}{|c|}{ Selection of profession: } \\
\hline & $\begin{array}{c}30 \\
\text { or less }\end{array}$ & $31-40$ & $\begin{array}{c}\text { above } \\
40\end{array}$ & $\begin{array}{l}\text { Village/ } \\
\text { small town }\end{array}$ & $\begin{array}{c}\text { town with } \\
\text { population } \\
\text { of } 20-100 \\
\text { thousand }\end{array}$ & $\begin{array}{c}\text { above } \\
100,000 \\
\text { residents }\end{array}$ & independent & persuaded & chance \\
\hline $\begin{array}{l}\text { increased satisfaction connected } \\
\text { with practicing the profession of pharmacist }\end{array}$ & $48.31 \%$ & $36.96 \%$ & $44.23 \%$ & $34.88 \%$ & $61.02 \%$ & $37.65 \%$ & $47.01 \%$ & $37.25 \%$ & $47.37 \%$ \\
\hline Pearson’s Chi^2 & \multicolumn{3}{|c|}{$1.58557, \mathrm{df}=2, \mathrm{p}=0.453$} & \multicolumn{3}{|c|}{$9.747514, \mathrm{df}=2, \mathrm{p}=0.008$} & \multicolumn{3}{|c|}{ 1. $4451, \mathrm{df}=2, \mathrm{p}=0.485$} \\
\hline higher salaries of pharmacists & $37.08 \%$ & $26.09 \%$ & $17.31 \%$ & $23.26 \%$ & $33.90 \%$ & $28.24 \%$ & $27.35 \%$ & $33.33 \%$ & $26.32 \%$ \\
\hline Pearson's Chi^2 & \multicolumn{3}{|c|}{$6.478172, \mathrm{df}=2, \mathrm{p}=0.039$} & \multicolumn{3}{|c|}{$1.402899, \mathrm{df}=2, \mathrm{p}=0.496$} & \multicolumn{3}{|c|}{$0.686575, \mathrm{df}=2, \mathrm{p}=0.709$} \\
\hline $\begin{array}{l}\text { improving the effectiveness of } \\
\text { pharmacotherapy }\end{array}$ & $51.69 \%$ & $58.70 \%$ & $53.85 \%$ & $44.19 \%$ & $57.63 \%$ & $56.47 \%$ & $56.41 \%$ & $56.86 \%$ & $31.58 \%$ \\
\hline Pearson's Chi^2 & \multicolumn{3}{|c|}{$0.6007773, \mathrm{df}=2, \mathrm{p}=0.740$} & \multicolumn{3}{|c|}{$2.18868, \mathrm{df}=2, \mathrm{p}=0.335$} & \multicolumn{3}{|c|}{$4.287185, \mathrm{df}=2, \mathrm{p}=0.117$} \\
\hline $\begin{array}{l}\text { higher treatment effectiveness } \\
\text { and hence greater patient satisfaction }\end{array}$ & $49.44 \%$ & $41.30 \%$ & $36.54 \%$ & $44.19 \%$ & $37.29 \%$ & $48.24 \%$ & $47.01 \%$ & $29.41 \%$ & $63.16 \%$ \\
\hline Pearson's Chi^2 & \multicolumn{3}{|c|}{$2.378881, \mathrm{df}=2, \mathrm{p}=0.304$} & \multicolumn{3}{|c|}{$1.697641, \mathrm{df}=2, \mathrm{p}=0.428$} & \multicolumn{3}{|c|}{$7.668786, \mathrm{df}=2, \mathrm{p}=0.022$} \\
\hline less difficulty in getting to the doctor & $17.98 \%$ & $15.22 \%$ & $9.62 \%$ & $20.93 \%$ & $16.95 \%$ & $10.59 \%$ & $17.09 \%$ & $11.76 \%$ & $10.53 \%$ \\
\hline Pearson's Chi^2 & \multicolumn{3}{|c|}{$1.805614, \mathrm{df}=2, \mathrm{p}=0.405$} & \multicolumn{3}{|c|}{$2.663236, d f=2, p=0.264$} & \multicolumn{3}{|c|}{$1.120852 \mathrm{df}=2 \mathrm{p}=0.571$} \\
\hline improving the doctor-pharmacist relationship & $12.36 \%$ & $4.35 \%$ & $5.77 \%$ & $9.30 \%$ & $6.78 \%$ & $9.41 \%$ & $5.13 \%$ & $9.80 \%$ & $26.32 \%$ \\
\hline Pearson’s Chi^2 & \multicolumn{3}{|c|}{$3.202936, \mathrm{df}=2, \mathrm{p}=0.202$} & \multicolumn{3}{|c|}{$0.3481139, \mathrm{df}=2, \mathrm{p}=0.840$} & \multicolumn{3}{|c|}{$9.517982, \mathrm{df}=2, \mathrm{p}=0.008$} \\
\hline $\begin{array}{l}\text { increase in the prestige of the profession of } \\
\text { pharmacist }\end{array}$ & $42.70 \%$ & $50.00 \%$ & $42.31 \%$ & $25.58 \%$ & $59.32 \%$ & $43.53 \%$ & $48.72 \%$ & $47.06 \%$ & $10.53 \%$ \\
\hline Pearson’s Chi^2 & \multicolumn{3}{|c|}{$0.7812088, d f=2, p=0.677$} & \multicolumn{3}{|c|}{$11.51715, \mathrm{df}=2, \mathrm{p}=0.003$} & \multicolumn{3}{|c|}{$9.861576, d f=2, p=0.007$} \\
\hline
\end{tabular}


In order for the pharmacist to become a significant element of patient care in the social consciousness, the apothecary environment must take active steps to implement pharmaceutical care in the practice of Polish pharmacies. Among the pharmacists examined, a high level of acceptance for this form of care provided to patients by pharmacies is noticeable. Over $3 / 4$ of respondents confirmed that pharmaceutical care should be carried out in Polish pharmacies, because it can bring many benefits both for the profession and for the patient himself. For the profession of pharmacist there is no future in the ordinary dispensation of medicines, because the apothecary can successfully be replaced by technicians or the Internet in that particular role [23].

In Iskierski and Zimmerman's studies, only every fifth pharmacist was ready to provide pharmaceutical care [24], in Dulian et al. research only $41 \%$ of pharmacists were ready for organizational changes in the pharmacy [25], and in Jankowski's studies, every second pharmacist was not interested in collecting information about medicines during pharmaceutical interviews, and $38.5 \%$ thought that only a doctor is appointed to solve medicine-related problems of patients [26]. However in our own research more than every tenth pharmacist declares that he or she currently carries out pharmaceutical care in his/her pharmacy, which is close to the results obtained by Jankowski [26].

The level of concerns of pharmacists related to the lack of preparation for conducting pharmaceutical care is still high. Many studies (including our own) identify the lack of confidence of pharmacists in their own capabilities to provide such care (lack of substantive knowledge, communication skills, interaction standards, etc.) $[23,24]$. It turns out that not the financial or spatial barriers are the greatest obstacle for pharmacists, but the subjective conviction about their lack of competence.

\section{CONCLUSIONS}

The analysis of the conducted research allowed us to observe contradictions in the attitudes of the pharmacists towards pharmaceutical care.

1. On the one hand pharmacists, realizing the importance of implementing this form of patient care in a pharmacy, confirm the necessity of running it, on the other they have many concerns related to it and identify significant barriers that impede the current implementation of pharmaceutical care.

2. The research demonstrates that younger and less experienced pharmacists are more receptive to pharmaceutical care, assess their competences higher and have fewer fears about taking over responsibility for the patient. It can be hoped that it is the young generation of pharmacists that will be the precursor on the road to the practical and widespread implementation of modern pharmaceutical care, which will improve the quality of life of patients, but also contribute to the growing importance of the profession of pharmacist in the field of public health.

\section{REFERENCES}

1. Sansgiry SS, Bhansali AH, Bapat SS, Qingqing X. Abuse of over-thecounter medicines: a pharmacist's perspective. Integr Pharm Res Pract. 2017;6:1-6.

2. Wazaify M, Shields E, Hughes CM, McElnay JC. Societal perspectives on over-the-counter (OTC) medicines. Fam Pract. 2005;22(2):170-6.

3. Piecuch A, Kozłowska-Wojciechowska M. Self-medication in Poland: the pharmacist's advisory role in Warsaw. Int J Clin Pharm. 2013;35(2):225-9.

4. Bond $\mathrm{C}$, Hannaford $\mathrm{P}$. Issues related to monitoring the safety of over-thecounter (OTC) medicines. Drug Saf. 2003;26(15):1065-74.

5. Marie-Claire Van Hout, Norman I. Misuse of non-prescription codeine containing products: Recommendations for detection and reduction of risk in community pharmacies. Int J Drug Policy. 2016;27:17-22.

6. James E. Lessenger, Feinberg SD. Abuse of Prescription and Over-theCounter Medications. J Am Board Fam Med. 2008;21(1):45-54.

7. Soller RW. Evolution of self - care with over the counter medications. Clinical Therapeutics. 1998;20(Suppl. C):134-40.

8. Wdowiak L, Lang B, Bojar I, et al. Self-medication - who buys OTC drugs in Poland? Zdr Publ. 2006;116(4):578-82.

9. CBOS, Leki dostępne bez recepty i suplementy diety. Warszawa; 2016. $\mathrm{Nr} 158 / 2016$

10. Wazaify M, Kennedy S, Hughes CM, McElnay JC. Prevalence of over-thecounter drug-related overdoses at Accident and Emergency departments in Northern Ireland - a retrospective evaluation. J Clin Pharm Therap. 2005;30:39-44.

11. Lipski S. O wzajemnych oddziaływaniach leków. Farm Pol. 2002;13:6427.

12. CBOS, Opinie o błędach medycznych i zaufaniu do lekarzy. Komunikat z badań. Warszawa; 2014. Nr 165/2014.

13. Okularczyk M, Brandys J. Promocja zdrowia jako element działalności aptekarzy. Farm Pol. 2002;58(15):734-9.

14. Waszyk-Nowaczyk M, Simon M. Znaczenie porady farmaceuty w procesie samoleczenia się pacjentów. Farm Pol. 2009;65(11):772-4.

15. Łazowski J. Opieka farmaceutyczna. Część I. Uwagi wstępne. Farm Pol. 2001;57(11):503-10.

16. Olejniczak-Rabinek M. Opieka farmaceutyczna wyzwaniem nie tylko farmaceutów. In: T. Malarczyk (ed). Zarządzanie wiedzą w regionie. Rola pielęgniarki w nowoczesnym leczeniu ran przewlekłych. Nysa: Oficyna Wydawnicza PWSZ; 2010. p.31-5.

17. Kotecki JE. Factors related to pharmacists' over the counter recommendations. J Community Health. 2002;27(4):291-316.

18. Stożkowska W. Rola opieki farmaceutycznej w ochronie zdrowia. Farm Pol. 2002;58(11):523-6.

19. Ustawa o izbach aptekarskich. Dziennik Ustaw Nr 136 z 29 lipca 2008 r. poz. 856.

20. Wapniarska I, Stożkowska W. Rola farmaceutów w terapii chorób cywilizacyjnych. Farm Pol. 2005;61(12):569-74.

21. Ulatowska-Szostak E. Lekomania i nadużywanie leków w opiniach wybranej grupy fachowych pracowników aptek. Probl Higieny i Epidemiol. 2006;87(suplement):36.

22. Latoszek M. Społeczna rola zawodu aptekarza na tle zastosowań opieki farmaceutycznej. Farm Pol. 2002;58(15):746-52.

23. Waszyk-Nowaczyk M, Simon M. Problemy związane z wdrażaniem opieki farmaceutycznej w Polsce. Farm Pol. 2009;65(10):713-5.

24. Iskierski J, Zimmermann A. Społeczna rola zawodu aptekarza w oczach własnych i pacjentów. Farm Pol. 2006;62(5):210-7.

25. Dulian K, Skrabalak M, Kamiński R, Stożkowska W. Edukacyjna rola farmaceuty w farmakoterapii w świetle opinii pracowników aptek. Farm Pol. 2003;59(17):792-4.

26. Jankowski A, Bułaś L, Jaros K. Ocena realizacji opieki farmaceutycznej w aptekach regionu Podbeskidzia. Farm Pol. 2007;63(2):57-61.

\section{Corresponding author}

Dr Anita Majchrowska

Independent Medical Sociology Unit, Faculty of Health Sciences

Medical University of Lublin

Staszica St. 4/6, Lublin 20-081, Poland

tel.: 814485650

E-mail: anita.majchrowska@umlub.pl 